\title{
MIKLÓS HORTHY IN POLAND. \\ OFFICIAL VISIT, IMAGE OF CHARISMATIC LEADER AND HIS LEADER CULT. THE HUNGARIAN INTERPRETATION ${ }^{1}$
}

\author{
DÁVID TURBUCZ \\ Research Centre for Humanities, Hungarian Academy of Sciences \\ turbucz.david@btk.mta.hu
}

\begin{abstract}
After the First World War, the leader cult was a widespread phenomenon in Europe. These cults manifested themselves around the figure of political and military leaders, such as Hitler, Franco, Mussolini, Hindenburg, Metaxas, Mannerheim, Piłsudski, Horthy and so on. After giving a short overview of the evaluation of the Horthy cult, this paper will focus on the official visit of the Hungarian Regent, Miklós Horthy (1920-1944) in Poland, in February 1938. This case study makes an attempt to demonstrate some aspects of the image of a charismatic leader. The aim of this paper is to show how the Hungarian News Agency and the selected Hungarian dailies used statements from the Polish press to justify the position of the Regent as national leader with extraordinary qualities. This paper will also endeavour to show how these statements may have contributed to the preservation of the charismatic image of Horthy. His extraordinary qualities were emphasized, such as his imagined deeds, his indispensability, his mission and the "fact" that he was chosen, as well as being a "saviour". Horthy and Piłsudski were compared to each other to bolster the larger-than-life image of Miklós Horthy. His charismatic image was composed of these above-mentioned elements.
\end{abstract}

Keywords: Miklós Horthy, Regent, interwar Hungary, leader cult, charismatic leadership, charisma, Hungarian-Polish relations

After the First World War leader cults appeared in several European states. The reason for their emergence were social, political tensions, crisis situations, and as such were all in all negative consequences of the First World War (see, for instance Kershaw 2001.; Hein 2002.; Petrakis 2006.; Hoegen 2007., Goltz 2009.; Plamper 2012.; Duggan 2013.). ${ }^{2}$

A leader cult is an excessive admiration for a political and/or a military leader who is depicted as being the only one being capable of solving a critical situation, of restoring lost national glory and greatness. The selectively constructed, more or less fictitious image of the leader is composed of several layers and elements and it is used to justify his elevated position, extraordinary qualities and personality, the so-called charisma (Turbucz 2015: 25-26.). Max Weber started using the term 
charisma for the purposes of political analysis (Weber 1978: 241-254.). Weber's concept however has been criticized and re-thought (Potts 2009: 116-136.). One of the most important modifications is that charisma is a construction (Plamper 2004: 35.; Kallis 2006: 25-43.; Apor 2010: 37-38.; Strong-Killingsworth 2011: 391-411.). ${ }^{3}$ This paper also emphasizes that it is indeed a construction. It can be identified with those elements of the leader's image that justify the leader's extraordinary qualities (Turbucz 2015: 28-29.).

From Portugal to Russia, from Greece to Finland leader cults emerged after the First World War in Europe. The secondary literature on these cults show that these cults can be divided into two groups: the cults of military and of political leaders. Hitler's leader cult, for example, emerged in a political party. Józef Piłsudski (1867-1935), the Marshal of Poland and Miklós Horthy (1868-1957), the Regent of Hungary, for instance, were first military leaders. Leader cults were constructed around Horthy and Piłsudski, too. The emergence of their leader cults cannot be separated from their military career. Later both became political leaders. Every interwar leader was depicted as a "saviour" by contemporaries participating in cult-making. In accordance with the above-mentioned aspect of leader cults there were two types of "nation-saving": 1. military (for instance, to defeat the enemy in a war or in a civil war), and 2. political (for instance, to solve a critical political situation after seizure of power). 'Nation-saving' was also attributed to Horthy and Piłsudski (Turbucz 2015: 38., 45-46.). ${ }^{4}$ The 'saviour' image was based on, first of all, their military career. It was an integral element of their leader cults. ${ }^{5}$

This paper primarily deals with the way the Hungarian News Agency, the analysed Hungarian dailies and János Kertész's 28-page book (Kertész 1938.) used statements from the Polish press in order to justify the position of the Regent as national leader with extraordinary qualities. This article aims to demonstrate through the depiction of the Regent's official journey to Poland how these statements may have bolstered the extraordinary qualities and personality of Miklós Horthy. It also seeks to show how this journey was integrated into the Horthy cult in Hungary (Varga E. 2001: 573-595.; Debreceni 2014: 127-137.). ${ }^{6}$ The reports of the Hungarian News Agency summarized what the Polish press wrote about Miklós Horthy before and during his journey. These reports were integrated into the coverages published in Hungarian dailies. Therefore these statements were incorporated into the charismatic image of Horthy. The articles published in the Polish press have not been analysed. Thus, this study is only based on the Hungarian News Agency's reports and the articles in the Hungarian dailies. János Kertész's book also summarizes the events of this official journey which reviewed Polish dailies using several quotations. All in all, this paper is concerned about the way the statements from the Polish press were interpreted in Hungary. The reason why this article concentrates on only Hungarian primary sources (the 
Hungarian News Agency, the Hungarian dailies and Kertész's book) is that Hungarian public opinion was not influenced directly by Polish dailies.

\section{An overall overview of Horthy cult and its context}

It is necessary to refer shortly to some important aspects of Miklós Horthy's leader cult. The Horthy cult was a consequence of the collapse of historical Hungary after the First World War. According to his official image Miklós Horthy was destined to restore the lost national glory, and to regain lost territories (Trianon Peace Treaty, 1920). As a result of Trianon the area of Hungary was reduced from 282.000 square kilometres in 1918 to $93.000 \mathrm{sq}$. km. and the country's population from 18.2 million in 1918 to 7.6 million. 3.2 million Hungarians continued living in successor states ${ }^{7}$ after Trianon.

The Horthy cult commenced in 1919, after the end of Bolshevik dictatorship, when Horthy, the last commander in-chief of the navy of Austria-Hungary became the symbolic leader of the counter-revolution. The most important events of his early leader cult were his entry into Budapest on $16^{\text {th }}$ November 1919 and the campaign in February 1920 before he was elected the Regent of Hungary.

This leader cult existed between 1919 and 1944 but, of course, its intensity and emphasis kept changing. In the first part of the twenties the cult-building process was not a dominant phenomenon. In the middle of the twenties, in connection with the stabilization of Hungary, the Horthy cult was elevated at state level. From then on, the whole state apparatus in association with the traditional churches, local authorities, non-governmental organizations, public education etc, built and preserved the Regent's cult. The number of participants and contributors in this cult building gradually increased after 1925. There was no Propaganda Ministry in Hungary during that time, but there is enough evidence to suggest that the government played a decisive role in cult-making. The contemporaries used different techniques to preserve the (charismatic) image of Miklós Horthy: mass media, biographies, history textbooks, paintings, placards, postcards, stamps and so on. The most important occasions of cult-building were the anniversaries related to the Regent. Among these the most significant were his birthday (18 $8^{\text {th }}$ June) and name day ( $6^{\text {th }}$ December $)$, the anniversaries of his "reign" ( $1^{\text {th }}$ March), and of his entry into Budapest (16 $6^{\text {th }}$ November). The cult, which functioned as a system, had different important stages: from Budapest to the provinces, from the Parliament through churches to schools. The official image of Miklós Horthy emphasized that successes achieved between 1919-1944 could not be separated from the national leader of Hungary. It was the reason why Horthy became the "saviour" of Hungary in 1919 and, later, in the twenties, in connection with the stabilization he became the "architect" of a new country. It is essential to note that the real role 
of the Hungarian Regent was not emphasized, but the exaggerated, imagined, propagandistically interpreted role of Miklós Horthy.

Horthy visited Italy in 1936 - it was his first official visit abroad - and Poland and Germany in 1938. According to the official interpretation, these journeys and the Regent's above mentioned "deeds" were steps towards the Hungarian "resurrection". It was reported that the respect of Hungary had gradually increased in Europe. ${ }^{8}$

\section{The events of the state visit in Poland}

Before 1936 Horthy hadn't been on official journeys abroad because of lack of invitations. The reason for this was the so-called White Terror in 1919-1920 and the fact that Horthy did not allow Charles IV to return onto the Hungarian throne in 1921. As a result, the Prime Ministers, for instance István Bethlen and Gyula Gömbös represented Hungary in international relations. Due to a change in the international climate (for example, more authoritarian regimes were present in Europe) Miklós Horthy had more possibility to travel abroad. The Regent's first non-official visit took place in 1936, when Horthy met Hitler (Romsics 2007: 14-15.). From the point of view of diplomacy his visit in Germany during the Czechoslovak crisis was the most important among his journeys between 1936 and 1938 (Pritz 1974).

Hungarian-Polish relations intensified after 1934. This resulted in Horthy's journey to Poland some years later. After lengthy preparation Miklós Horthy and the Hungarian delegation visited Poland in early February 1938 (Varga E. 2001: 578-581.). They arrived in Kraków $5^{\text {th }}$ February at around 9 o'clock in the morning. ${ }^{9}$ The Mayor of Kraków had issued an instruction in which he had asked the inhabitants of the city to display flags and national colours on their own houses. ${ }^{10}$ In Kraków the Regent of Hungary was welcomed by Marshal Edward Rydz-Śmigły, the Marshal of Poland; Ignacy Mościcki, the Head of the State of Poland and the representatives of Kraków. ${ }^{11}$ The analysed Hungarian dailies gave detailed accounts of the events of this journey. ${ }^{12}$ Among these dailies are radical right (Függetlenség), conservative (Budapesti Hirlap, 8 Órai Újság, Új Nemzedék), liberal (Pesti Hirlap, Pesti Napló) and social democrat (Népszava) dailies. When observed regarding content and length of the published articles there were no obvious differences between these dailies. Népszava was the only exception. It reported on the journey only in a limited, moderate manner. Népszava expressed its opposition to the Hungarian government in this way. ${ }^{13}$ The other Hungarian dailies that belonged to the opposition did not refrain from cult-building process.

Horthy, Rydz-Śmigły, Mościcki and others had a solemnly welcome from the railway station into the centre of town. ${ }^{14}$ The windows were adorned with the 
portrait of Horthy. ${ }^{15}$ After entering the city the Regent laid a wreath at the tomb of Piłsudski and of István Báthory. ${ }^{16}$ Later Rydz-Śmigły and Mościcki had a private discussion with the Regent. ${ }^{17}$ In the afternoon Horthy visited some public places, institutions that played a role in Hungarian history. ${ }^{18}$ Receptions and social events also took place during this visit. ${ }^{19}$ On $6^{\text {th }}$ February the Hungarian delegation left Kraków. ${ }^{20}$ The Regent took part in a hunt in Bialowiezsa between $6^{\text {th }}$ and $8^{\text {th }} \mathrm{Feb}-$ ruary. ${ }^{21}$ On $8^{\text {th }}$ and $9^{\text {th }}$ the Ministers of Foreign Affairs negotiated with each other in the Polish capital, Warsaw (Varga E. 2001: 585-588.). The most important topic was Czechoslovakia whose future became uncertain because of Germany's foreign policy. Hungary and Poland were also hostile to Czechoslovakia. ${ }^{22}$ As opposed to the similar interests both of Hungary and Poland against Czechoslovakia, the only conclusion of this visit was that the two Foreign Ministers made an arrangement concerning the exchange of information between the Hungarian and Polish government regarding Czechoslovakia and the Central European region. Miklós Horthy had no decisive role in this arrangement. On the whole, the Foreign Ministers regarded the visit as being unsuccessful (Varga E. 2001: 585-592.). On $9^{\text {th }}$ February Horthy visited Warsaw where he laid a wreath at the tomb of The Unknown Warrior. ${ }^{23}$ Horthy left for Hungary on this day. ${ }^{24}$

It should be sufficient to give a short overview of these days because this journey was organized in accordance with diplomatic protocol. From the point of view of the Horthy cult, it is of greater importance to analyse how this journey was interpreted by cult-makers. How it was integrated into the narrative of Horthy cult is of greater significance.

\section{The interpretation of the Regent's visit}

The most important messages from the Polish press were used by the Hungarian News Agency. Hungarian dailies and János Kertész's 28-page book were implemented to justify the elevated position of the Hungarian Regent. This analysis focuses on these statements. Among these messages the extraordinary qualities of the Regent can be found, such as his imagined deeds, his indispensability, his mission and the "fact" that he was chosen, in addition to being a "saviour". His charismatic image was composed of these elements.

Some weeks before the journey Gazeta Polska emphasized that Miklós Horthy had a crucial role in the struggle against Bolshevism after the First World War. ${ }^{25}$ In another article of Gazeta Polska it was unambiguously underlined that:

"Regent Miklós Horthy became the leader of the Hungarian state when a new life began in Hungary after the First World War. He was the leader of the Hungarians bloody and victorious struggle against 
Bolshevism. Horthy was leading his nation towards regeneration and resurrection under inexpressible conditions. Due to his guidance the reforms were completed". ${ }^{26}$

An article published in Maly Dziennik, a daily that supported the Polish Catholic Church, it expressed that in 1919 Miklós Horthy had raised an army and "liberated" Hungary from the Bolshevik dictatorship. ${ }^{27}$ In these articles 1919, the year when the political role of Miklós Horthy started, was depicted as a turning point in Hungarian history. The appearance of Miklós Horthy as a supreme commander of the National Army in 1919 was seen by journalists as a clear break with the near past, with the fateful events between 1918 and 1920, such as the defeat (1918), the bourgeois democratic revolution symbolized by Mihály Károlyi (1918), the Bolshevik dictatorship led by Béla Kun (1919), the occupation of Hungary by the Romanian army (1919). 1919, this symbolic turning point in Hungary, marked both the promise of a brighter future and the beginning of a new, renewed era, the so-called Christian-national period in Hungary, when the nation was victoriously "resurrected". To sum up, it "symbolized a break with the liberal past and with everything that led to the revolutionary catastrophes. It also symbolized a nation reborn from an apocalyptic death" (Hanebrink 2006: 135.). The similarity with Christianity is obvious, the resurrection of Jesus Christ in the Christian tradition also marked something new, something better, the promise of salvation and eternal life (Kula 2005: 372.). According to this propagandistic interpretation from 1919 onwards Horthy led the Hungarian nation resolutely and determinedly towards the so-called "brighter future", the Hungarian national "resurrection". Those who highly praised Miklós Horthy stated that he could better conditions in Hungary. It was, of course, an absolute bipolar interpretation. The main messages of this view, such as the break with the past, the symbolic beginning of a new period and the struggle between "good" and "evil", which are outlined in the previous quotation, were integral elements of the Horthy image between 1919 and 1944 in Hungary. ${ }^{28}$

Horthy was portrayed as a "national hero" in the Polish press whom Providence had chosen, blessed and sent after the First World War to lead the Hungarian nation towards the "Hungarian resurrection". According to Ilustrowany Kuryer Codzienny, one of the mouthpieces of the Polish government:

\footnotetext{
"In the person of our respected guest, the Regent of Hungary Kraków and the whole Polish nation welcomes the head of the friendly Hungarian nation and the great man, national hero, whom Providence gave to the Hungarian nation after the critical years of the Great War. [...] It was the manifestation of Providence's will that Horthy appeared in Hungary when thrones collapsed, and everything changed. He had enough spirit, strength and heroic patriotism to become leader and saviour." 29
} 
On $7^{\text {th }}$ February the Hungarian News Agency reported: "The Kurjer Wilenski writes that for Hungary, Regent Horthy is a man sent by Providence". ${ }^{30}$ The references to the will of God were also integral elements of Horthy's image. It was one of the most important irrational elements of his image. In order to bolster his leadership, to demonstrate his entitlement to this position, to strengthen his legitimacy, Horthy was depicted as a chosen leader, whom the God of the Hungarians had chosen, blessed and sent to lead the Hungarian nation to a "better future". Therefore, Miklós Horthy, the God-given leader, whose deeds were described as the fulfillment of the will of divine providence, was an envoy, an instrument of God. If the Almighty is on our side, journalists frequently argued, there is no reason to fear the future. Everything will be solved; national glory will be restored - the propagandists stated.

What is more, God was often illustrated as a "national God", the God of the Hungarians in the cultic texts. According to this, based on specific chapters of the Old Testament, there was a special relationship between the Hungarian nation and the God of the Hungarians. This interpretation emphasized the selectness both of the leader and of the nation. The Hungarian nation was characterized as a chosen nation in the reports of the Hungarian News Agency and in the Hungarian dailies. ${ }^{31}$ As a result, according to these texts, the Hungarian nation was never forsaken in its history because "our" God always took care of "us". It was the reason why Miklós Horthy was chosen and sent in 1919, at a moment of crises, to save "us" and lead "us" towards a better future. Therefore, according to the analysed interpretation there was a special relationship between Horthy and Providence. Horthy and the community led by him had a special role in God's plan - the cult-makers ${ }^{32}$ stated regularly. Therefore the mission of Miklós Horthy as a "saviour" was described as divine intervention. His mission was a God-given mission - the contemporaries emphasized participating in cult-building. The expression "promised land" cannot be found in the evaluated articles, nevertheless it was an integral element of this interpretation. It was the reason why historical Hungary (before Trianon) was equated with the so-called "promised land". 33

According to Béla Földes, a Hungarian journalist, the correspondent of the Hungarian liberal daily called Pesti Hirlap in Warsaw, Horthy was one of those leaders who "saved" their nations and countries from internal and/or external threats after the First World War. He argued that it was one of the reasons why Horthy, the "hero of Novara" became a national leader and "captain" of Hungary. The cult-makers very often referred to Hungary as a ship. "The Hungarian nation was lucky that fate sent Miklós Horthy to the bridge" - stated Béla Földes. He was not the only one who shared this belief between 1919 and 1944. According to this approach Horthy did "save" both Hungary and "European culture and civilization” from Bolshevism in 1919. 
"After Horthy expelled the communist hordes from Hungary and liberated his country from occupation he organized the National Assembly, ${ }^{34}$ that unanimously elected him Regent of Hungary. Now the European significance of Regent Miklós Horthy is obvious. He was the one who made the existence of Communism impossible in the heart of Europe, in Hungary".

With this statement Béla Földes supported the comparison between post-World War Poland and Hungary. The result of this comparison was that Poland and Hungary determinedly fought against Bolshevism after the First World War. Földes stated that Józef Piłsudski had been the "saviour" in Poland who had defeated the Red Army in Warsaw in 1920. Regarding this statement it is important to note that during Horthy's visit in Poland the references to the fact that Hungary supported Poland during the Polish-Soviet War in 1920 were indeed frequent (Varga E. 2001: 583.). Based on the report of the Hungarian News Agency Földes added that:

\footnotetext{
"Marshal Piłsudski with his glorious military talent regained the distressed independence of Poland when he defeated and expelled the Red Army in Warsaw. Was the fate of the two nations the same again? -the article's author asks. The map of Europe would be different if the bloody dictatorship of Béla Kun had not been destroyed in Hungary and if Marshal Piłsudski with his iron hand had not defeated the red wave". ${ }^{35}$
}

Hence the constructed leader's image of Horthy and of Piłsudski were connected to each other. In this article both of them were seen as "saviours" against Bolshevism. There were other examples of comparisons between Józef Piłsudski and Miklós Horthy in February $1938 .{ }^{36}$ The Express Poranny stated on $5^{\text {th }}$ February: "We admire the national hero [Miklós Horthy - D. T.] who liberated Hungary from Communism, and similarly Piłsudski he saved Europe from the great threat" ${ }^{37}$ A radical right Hungarian daily, Függetlenség also compared Horthy with Piłsudski when it published quotations from the above-cited article of Express Poranny. ${ }^{38}$

This historical comparison was integrated into the official image of Miklós Horthy as "national saviour". It was used to emphasize and to justify the Regent's anti-Bolshevist commitment and his "successes" in the struggle against Bolshevism. This comparison may have contributed to bolstering his larger than life image. Nevertheless, there was an essential difference between Piłsudski and Horthy: Józef Piłsudski participated in the War against the Red Army in 1920, but Horthy did not take part in military actions against the Hungarian Red Army in 1919. What is more Piłsudski had a leading role in the mentioned war (Sakmyster 1994: vii-viii., 19-89.; Norman 2003.). Although a leader cult was also built 
around the figure of Józef Piłsudski. Because of cult-making his military successes were evaluated in a simplified, selective and idealized way. The "saviour of Poland" was an integral element of his official image, but it had real basis (Hein 2002.). The Bolshevik dictatorship of 1919 in Hungary (led by Béla Kun) did not collapse because of the counter-revolution symbolised by Miklós Horthy. The reason for its collapse was the Romanian Army that attacked Hungary in summer of 1919 and occupied the majority of its territory some weeks later (Romsics 1999: 99-108.). In the case of Piłsudski there were real successes, however the same cannot be stated about the role of Horthy. If we observe the real base of his constructed image, the reality underlying it, is simply Miklós Horthy's determined anti-Bolshevism. There were no military actions against the Hungarian Red Army led by him in 1919. As opposed to reality, the image of Miklós Horthy as victorious anti-Bolshevik leader was an oversimplified, selective and fictive construction. The gulf between the genuine Horthy and his image was striking; indeed it clearly shows how the inter-war leader cults worked. The cult-makers usually neglect those aspects of reality that (may) weaken the leader cult's effectiveness (Rees 2004: 3-26.).

Most of the articles published in the Polish dailies gave an overview of what Horthy did between 1919 and 1938 for Hungary. Almost every success, triumph and positive outcome was attributed to the Regent. His indispensability was emphasized. An article titled "The great creation of Miklós Horthy" was published in Gazeta Polska on $4^{\text {th }}$ February. The Hungarian News Agency reported this article in the following way: this Polish daily on the first page "[...] deals with the Regent's heroic behaviour during communism and the counter-revolution. ${ }^{39}$ Regent Miklós Horthy took Hungary out of its critical situation instinctively and safely. He became the leader of the National Army at the most critical moment. He forced the Romanian army to leave the Hungarian capital". ${ }^{40}$ In another article Horthy was portrayed as a "strong" man who is leading his nation from "darkness" to "light". ${ }^{41}$ The Budapesti Hirlap took a short statement from a report of the Hungarian News Agency to evaluate the role of Miklós Horthy as Regent. It was originally published in a Polish daily. Miklós Horthy "saved Hungary from post-war anarchy and he guided his nation on the route to resurrection" ${ }^{42}$ The analysed articles underlined that after the Bolshevik dictatorship of 1919 Horthy had started leading the nation towards "rebirth" and "regeneration". ${ }^{43}$ On $30^{\text {th }}$ January a professor of the University of Krakków published an article in Czas in which he stated that "in the previous years Hungary was strengthened economically and consolidated socially. Hungary regained its international respect due to its reliable and strong friends". The author attributed these successes, first of all, to the "wise" Regent (Kertész 1938: 2.). Because of Miklós Horthy's "wise" decisions Hungary regained its international authority. Hungary is again a country that is "respected" in Europe. ${ }^{44}$ The cited assertions show that everything, every 
positive achievement was attributed to Miklós Horthy. It was explained by his "extraordinary" qualities. In some cases it was expressed by concrete examples (for instance, "Miklós Horthy forced the Romanian Army to leave Hungary"). In other cases, which were much more frequent, the words "rebirth", "regeneration", "resurrection" were used to emphasize the "extraordinary" role of the Regent.

Between 1919 and 1938 very oversimplified and exaggerated statements were published in the Polish and the Hungarian press regarding Miklós Horthy's role. The extent to which Horthy participated in decision-making changed in the inter-war period. Between 1919 and 1921 and after 1930 his role was more active than in the 1920s when he fulfilled almost only his representative functions. With some exceptions the role of the Prime Ministers and Ministers were far more important and determining than the role of Horthy as Regent. ${ }^{45}$ It also underlines one of the most important characteristics of leader cults because every success is exclusively attributed to the leader in whom the so-called "collective wishes" are concentrated (Rees 2004: 5., 14.; Casssirer 1946: 277-296.).

The Polish dailies used the above-mentioned statements, symbols and motifs in order to justify why the Polish nation enthusiastically celebrated Miklós Horthy. In the Polish and Hungarian press this visit was interpreted as a "triumphal". It emphasized that the Hungarian Regent was "extraordinary" and a "unique" personality. ${ }^{46}$ A Hungarian liberal daily, Pesti Napló used, for example, the words "intoxicating enthusiasm" and "regal pomp". ${ }^{47}$

\section{Summary}

Anniversaries played a dominant role in the building of leader cults, however recurring events are not only integrated into this system. There are, of course, one-off events which may also contribute to bolstering leadership. These events and their press coverage may confirm the leaders' larger than life (charismatic) images.

The analyzed visit is one of these examples. Despite the fact that it was not successful, and it had no obvious results, this journey was seen as a "triumph" and it was used to preserve the charismatic image of Miklós Horthy. The Hungarian News Agency's reports outlined the content of those relevant articles which were published in Polish dailies. As a result of the Hungarian News Agency the Hungarian press may have disseminated these statements, the most important elements of the official Horthy-image. Those messages were frequent which could more or less be connected to this journey. First of all, the comparison between Horthy and Piłsudski was the most important. In this respect the anti-Bolshevist sentiments were emphasized. Horthy and Piłsudski were also described as "bulwarks" against Bolshevism and as "extraordinary" personalities. The fact that 
Horthy was praised in the Polish press was used by the Hungarian dailies in order to justify that Horthy is a "popular" and "respected" political figure, not only in Hungary but also in Europe. According to Budapesti Hirlap, a conservative daily, the Polish press wrote about Horthy in a "delightful" way. ${ }^{48}$ Ádám Romer, a journalist of Maly Dziennik, a catholic daily wrote on $17^{\text {th }}$ January that "the Regent's knightly figure is well-known not only in Poland but in Europe, too". ${ }^{49}$ The observed articles not only tried to justify his "popularity" but his extraordinary personality, such as his imagined deeds, his indispensability, his mission and the "fact" that he was chosen, and he was a "saviour". It is crucial to note that those elements of the Horthy-image that appeared in the Polish press had been used in Hungary. Thus, this Horthy image was not supplemented during the journey with the exception of the comparison between Horthy and Piłsudski.

There is evidence to state, for instance the reports of the Hungarian News Agency, that there was collaboration between Hungarian and foreign News Agencies and editorial offices. As a result of such exchanges of news the mentioned elements of Horthy image appeared in the Polish press. Among the authors were Hungarian journalists. There was extremely minimal reference in the Hungarian dailies with regard to the collaboration between the News Agencies and that Hungarian journalists also published articles in the Polish dailies. It was the reason why it may have seemed that the published articles in the Polish press represented Polish public opinion.

\section{Acknowledgements}

I would like to thank Attila Pók, Róbert Balogh, Ákos Bartha and Rudolf Paksa for their help and their suggestions.

References:

Books and papers

Apor, Balázs "Communist Leader Cults in Eastern Europe: Concepts and Recent Debates", in Cultic Revelations: Studies in Modern Historical Cult Personalities and Phenomena, ed. Anssi Halmesvirta (Jyväskylä-Pécs, 2010), 37-62.

Cassirer, Ernst, The Myth of the State. (New Haven: Yale University Press, 1946)

Davies, Norman, White Eagle, Red Star. The Polish-Soviet War 1919-1920 and 'the miracle on the Vistula'. (London: Pimlico, 2003)

Debreceni, Péter: "Horthy Miklós és Kánya Kálmán lengyelországi látogatása lengyel és magyar napilapok tükrében [The visit of Miklós Horthy and Kálmán Kánya in the mirror of Hungarian dailies]", in Tanulmányok a magyar történelemröl a kora uujkortól a legújabb korig. [Studies on the Hungarian history from early modern to modern history]. eds.: Döbör András-Zeman Ferenc (Szeged: Egyesület Közép-Európa Kutatására, 2014): 127-137. 
Duggan, Christopher, Fascist Voices. An Intimate History of Mussolini's Italy. (London: Vintage Books, 2013)

Gentile, Emilio, Politics as Religion. (Princeton-Oxford: Princeton University Press, 2006.)

Gerő, András, Imagined History. Chapters from Nineteenth and Twentieth Century Hungarian Symbolic Politics. (New York: Columbia University Press, 2006)

Goltz, Anna von der, Hindenburg. Power, Myth, and the Rise of the Nazis. (Oxford: Oxford University Press, Oxford, 2009)

Hanebrink, Paul A., In Defense of Christian Hungary. Religion, Nationalism, and Antisemitism, 1890-1944. (Ithaca-London: Cornell University Press, 2006)

Hein, Heidi, Der Pitsudski-Kult unde seine Bedeutung für den polnischen Staat 1926-1939. (Marburg: Verlag Herder-Institut, 2002)

Hoegen, Jesko von, Der Held von Tannenberg. Genese und Funktion des Hindenburg-Mythos. (Köln-Weimar-Wien: Böhlau Verlag, 2007)

Kallis, Aristotle A., 'Fascism, 'Charisma' and 'Charismatisation': Weber's model of 'Charismatic Domination' and Interwar European Fascism", Totalitarian Movements and Political Religions, 7/1. (2006): 25-43.

Kershaw, Ian, The 'Hitler Myth'. Image and Reality in the Third Reich (Oxford: Oxford University Press, 2001)

Kertész, János, Vitéz nagybányai Horthy Miklós kormányzó lengyelországi útja [The journey of Regent Miklós Horthy to Poland] (Budapest: Magyar Mickiewicz Társaság, 1938)

Kula, Marcin, Communism as Religion, Totalitarian Movements and Political Religions, 6/3. (2005): 371-381.

Petrakis, Martina, The Metaxas Myth. Dictatorship and Propaganda in Greece (Tauris Academic Studies: London-New York, 2006)

Plamper, Jan, The Stalin Cult. A Study in the Alchemy of Power (New Haven-London: Yale University Pres, 2012)

Plamper, Jan, "Introduction: Modern Personality Cults", in Personality Cults in Stalinism - Personenkulte in Stalinismus. eds.: Klaus Heller-Jan Plamper (Göttingen: V\&R unipress, 2004): $13-41$.

Potts, John, A History of Charisma (Basingstoke: Palgrave Macmillan, 2009)

Pritz, Pál: “A kieli találkozó (Forráskritikai tanulmány) [Meeting at Kiel.]”, Századok, 108/3. (1974): 646-680.

Rees, E. A, "Leader Cults: Varieties, Preconditions and Functions", in The Leader Cult in Communist Dictatorships. Stalin and the Eastern Bloc, ed. Balázs Apor et al. (London: Palgrave Macmillan, 2004): 3-26.

Romsics, Ignác: István Bethlen: A Great Conservative Statesman of Hungary, 1874-1946 (New York, Columbia University Press, 1995)

Romsics, Ignác: Hungary in the twentieth century. (Budapest: Corvina-Osiris, 1999)

Romsics, Ignác: "Horthy-képeink (Our Horthy-images)", Mozgó Világ, 33/10. (2007): 3-33.

Sakmyster, Thomas, Hungary's Admiral on Horseback. Miklós Horthy, 1918-1944. (New York. Columbia University Press, 1994)

Smith, Anthony D., Chosen Peoples. (Oxford-New York: Oxford University Press, 2003)

Strong, Carol-Killingsworth, Matt, "Stalin the Charismatic Leader: Explaining the 'Cult of Personality' as a Legitimation Technique", Politics, Religion \& Ideology, 12/4. (2011): 391-411.

Turbucz, Dávid, Horthy Miklós [Miklós Horthy]. (Budapest: Napvilág Kiadó, 2011)

Turbucz, Dávid, A Horthy-kultusz 1919-1944. [The Horthy Cult 1919-1944] (Budapest: MTA Bölcsészettudományi Kutatóközpont Történettudományi Intézet, 2015)

Varga E., László, “A kormányzó látogatása Lengyelországban 1938-ban [The Regent’s visit in Poland]”, Hadtörténelmi Közlemények, 114/4. (2001.): 573-595. 
Weber, Max, Economy and Society. An Outline of Interpretive Sociology Vol. 1. (Los Angeles: Berkeley, 1978)

Zeidler, Miklós: Ideas on Territorial Revision in Hungary 1920-1945. (New York: Columbia University Press, 2007)

\section{Notes}

1 This paper is an extended and corrected version of a presentation made at the conference "Hungary and Poland in Europe 1918-1939" in Warsaw on 27th October 2015. I have already dealt with the journey of Miklós Horthy to Poland in my monograph based on my $\mathrm{PhD}$ dissertation. In the chapter on the Regent's journeys abroad there is a very short analysis about the most important aspects of his official visit in Poland regarding cult-building process. Turbucz 2015: 193-198. This paper is a rewritten, corrected and extended version of relevant parts of this book.

2 There is an extensive literature on the leader cults in interwar Europe. I mention only some important books here.

3 The cited secondary sources are also the most important examples.

4 My analysis regarding these categories is based on the relevant secondary literature.

5 Regarding these leader cults see Hein 2002: op. cit.; Turbucz 2015: op. cit.

6 László E. Varga and Péter Debreceni have already dealt with this journey from the point of view of Hungarian diplomacy. Varga and Debreceni have not referred to the Horthy cult. This phenomenon was not an element in their analyses.

7 Concerning the history of Horthy-era, see for example Romsics 1999.; Romsics 1995; Regarding the life of Miklós Horthy, see Sakmyster 1994.

8 Concerning the detailed analysis of Horthy cult between 1919 and 1944 see my monograph cited in the first endnote.

9 MNL OL K 428. a) 29 January 1938. 25., 4 February 40. I would like to note that some reports were disseminated by the Polish News Agency.

10 MNL OL K 428. a) 3 February 1938. 1.

11 Ibid. 5 February 1938. 7.

12 For instance Budapesti Hirlap, 6. February 1938. 1-4.; Budapesti Hirlap, 10. February 1938. 1-2.; Pesti Napló, 6. February 1938. 2-4.; Pesti Napló, 9. February 1938. 7.; Új Nemzedék, 4. February 1938. 3.; 8 Órai Újság, 5. February 1938. 3.; Pesti Hírlap, 1938. február 6. 3-4.; Függetlenség, 5 February 1938. 1-2.; Magyarság, 10. February 1938. 2.

13 To the social democrat daily's articles see Népszava, 8 February 1938. 2.; Népszava, 10. February 1938. 5.

14 MNL OL K 428. a) 5. February 1938. 8.

15 Ibid. 5. February 1938. 14.

16 Ibid. 9. February 1938. 9.

17 Ibid. 5. February 1938. 13-14.

18 Ibid. 5. February 1938. 39-40.

19 Ibid. 5. February 1938. 39., 57.

20 Ibid. 6. February 1938. 1.

21 Ibid. 7. February 1938. 3-4., 10., 38., 8. February 7., 35.

22 To the Hungarian-Polish relations see Varga E. 2001: 573-577.; Debreceni 2014: 128.

23 MNL OL K 428. a) 9. February 1938. 23-24.

24 Ibid. 9. February 1938. 55-56., 10. February 17.

25 MNL OL K 428. a) 12 January 1938. 5.; Varga E. 2001: 583. 
26 Ibid. 12 January 1938. 16.

27 Ibid. 30 January 1938. 17.

28 To the motif of symbolic beginning, see for instance Turbucz 2015: 73-75., 151-152.

29 MNL OL K 428. a) 5 February 1938. 1.; Kertész 1938: 4.

30 MNL OL K 428. a) 7 February 1938. 39. This quotation from Kurier Wilenski was published in an article of Budapesti Hirlap (8 February 1938. 2.). This conservative daily took this statement from the cited report of the Hungarian News Agency.

31 MNL OL K 428. a) 1938. 5 February 1., 30-31., 6 February 12., 7 February 4., 39., 41. Budapesti Hirlap, 6 February 1938. 4.; Budapesti Hírlap 8 February 1938. 2.

32 Regarding the relationship between religion and national identity see Smith 2003: 48-51.; Gerö 2006: 259-266.

33 In relation to this element of the leader's image see Turbucz 2015: i. m. 66-67.

34 Miklós Horthy did not organized the National Assembly.

35 MNL OL K 428. a) 3 February 1938. 21.; Pesti Hirlap, 4 February 1938. 4.; Kertész 1938: 3.

36 See, for instance, MNL OL K 428. a) 5 February 1938.

37 MNL OL K 428. a) 5 February 1938. 31.

38 Függetlenség, 1938. 6 February 2.

39 The first part of this quotation that refers to Horthy's "heroic behavior" was published in the press review of Függetlenség (1938. 5 February 2.).

40 MNL OL K 428. a) 4 February 1938. 39.; Kertész 1938: 3.

41 MNL OL K 428. a) 7 February 1938. 39.

42 Budapesti Hirlap, 8 February 1938. 2.

43 MNL OL K 428. a) 3 February 1938. 34.

44 MNL OL K 428. a) 9 February 1938. 49.

45 To the real role of Miklós Horthy see Sakmyster 1994.; Turbucz 2011.

46 See, for instance, Budapesti Hirlap, 5 February 1938. 3.; Pesti Napló, 10 February 1938. 3.; 8 Órai Újság, 4 February 1938. 1.; Függetlenség, 6 February 1938. 1.; Pesti Hirlap, 11 February 1938. 1.

47 Pesti Napló, 6 February 1938. 2.

48 Budapesti Hírlap, 4 February 1938. 3.

49 MNL OL K 428. a) 17 January 1938. 30. 